Winter 2015

\title{
At Play in the Field of Law: Symbolic Capital and Foreign Attorneys in LL.M. Programs
}

Jan Hoffman French

University of Richmond, jfrench@richmond.edu

Follow this and additional works at: https://www.repository.law.indiana.edu/ijgls

Part of the International Law Commons, Legal Education Commons, and the Legal Profession

\section{Commons}

\section{Recommended Citation}

French, Jan Hoffman (2015) "At Play in the Field of Law: Symbolic Capital and Foreign Attorneys in LL.M. Programs," Indiana Journal of Global Legal Studies: Vol. 22 : Iss. 1 , Article 5.

Available at: https://www.repository.law.indiana.edu/ijgls/vol22/iss1/5

This Article is brought to you for free and open access by the Law School Journals at Digital Repository @ Maurer Law. It has been accepted for inclusion in Indiana Journal of Global Legal Studies by an authorized editor of Digital Repository@Maurer Law. For more information, please contactrvaughan@indiana.edu.

\section{$\Psi$}

JEROME HALL LAW LIBRARY

INDIANA UNIVERSITY

Maurer School of Law
Bloomington 


\title{
At Play in the Field of Law: Symbolic Capital and Foreign Attorneys in LL.M. Programs
}

\author{
JAN HOFFMAN FRENCH*
}

The article under consideration in this symposium issue, "Foreign Attorneys in U.S. LL.M. Programs: Who's In, Who's Out, and Who They Are," by Mindie Lazarus-Black and Julie Globokar, comes at a critical moment for law schools, especially those below the top tier. Many schools are reducing class size, offering unprecedented financial aid and scholarship packages, and entering a general retrenchment mode. This most recent crisis in law school applications and enrollment (applications are down at some schools by over 30 percent) ${ }^{1}$ has led to an increase in the popularity of Master of Laws (LL.M.) programs for foreign attorneys. The steep rise in the number and variety of law schools with LL.M. programs ${ }^{2}$ may be seen, at least in part, as a reaction to the power of the law school ranking system adopted in 1990 by U.S. News and World Report (USN). Even before this crisis, law schools were under pressure to "optimize their ranking by, for example, basing admissions decisions on LSAT scores" and by "spending more money on merit-based scholarships in order to 'buy' students whose LSAT scores [would] raise the school's median." 3 Crucial to

* Jan Hoffman French is Associate Professor of Anthropology at the University of Richmond ( $\mathrm{PhD}$ Anthropology Duke University, Durham, N.C.) and was a practicing attorney for fifteen years (JD University of Connecticut School of Law, Hartford, Conn.).

1. See Steven Davidoff Solomon, Potential Sale of Law School Raises Debate Over Who Should Profit, N.Y. TIMES, June 4, 2014, at B7 (reporting that total applications at law schools have declined 40 percent over the last few years).

2. As reported by Carole Silver, between 1998 and 2003, "graduate programs available to foreign law graduates increased more than fifty percent" with an increasingly diverse group of schools adding such programs to their offerings. Carole Silver, Internalizing U.S. Legal Education: A Report on the Education of Transnational Lawyers, 14 CARDozo J. INT'L \& COMP. L. 146 at 147 (2006).

3. Michael Sauder \& Ryon Lancaster, Do Rankings Matter? The Effects of U.S. News \& World Report Rankings on the Admissions Process of Law Schools, 40 L. \& Soc'Y REV. 105, 115 (2006); see also BRIAN Z. TAMANaHA, FAILING LaW SchOOLS 78, 97-98 (2012) (showing the rise in merit-based aid and the concomitant fall in need-based aid since 1994-95); Bryant G. Garth, Crises, Crisis Rhetoric, and Competition in Legal Education: A Sociological Perspective on the (Latest) Crisis of the Legal Profession and Legal Education, 24 STAN. L. \& Pol'Y REV. 503, 523 (2013).

Indiana Journal of Global Legal Studies Vol. 22 \#1 (Winter 2015)

(C) Indiana University Maurer School of Law 
understanding the recent rise in LL.M. programs is the exclusion of LL.M. programs from the USN ranking process. In other words, one way to bolster necessary finances and keep a law school's USN rank as high as possible is to establish or expand an LL.M. program that attracts lawyers from around the world who have the capacity to pay.

Since the very top-ranked law schools remain able to place their students in high-paying jobs, ${ }^{4}$ it is particularly important to consider, as Lazarus-Black and Globokar do, the effects of the LL.M. expansion trend on second-tier (and below) national and regional law schools. For those schools, the USN ranking loophole provides a welcome opportunity for raising funds that, it is hoped, will keep those law schools from falling even lower in the rankings. A fall in rank augurs a downward spiral in "quality" (as defined by ranking factors) ${ }^{5}$ and attractiveness to potential students and faculty, as well as a concomitant fall in applications, admissions, and income. Lazarus-Black and Globokar are interested in showing, through their research at two non-elite (most likely second-tier) law schools, ${ }^{6}$ that the LL.M. expansion trend is not solely the result of a financial strategy. The authors explain that the increase in foreign-lawyer students in LL.M. programs should also be understood as a positive development-one that adds important elements to law school life and practice. ${ }^{7}$

In this Comment, I would like to pick up a thread of the authors' analysis and, in so doing, shift the emphasis a bit. That thread relates to their use of Pierre Bourdieu's theoretical conceptualizations of "field" and "forms of capital." In their analysis of admissions essays submitted by foreign-lawyer applicants, Lazarus-Black and Globokar consider how

4. BRian Z. TamanaHa, Failing LaW Schools 112 (2012).

5. USN uses the following factors in determining law school rankings: subjective judgment by reputation (40\%); LSAT scores and GPAs (25\%); placement success (20\%); and faculty resources (including library) (15\%). Sam Flanigan \& Robert Morse, Methodology: 2015 Best Law Schools Rankings, US NEWS \& WORLD REPORT (Mar. 10, 2014), http://www.usnews.com/education/best-graduate-schools/top-lawschools/articles/ 2014/03/10/methodology-2015-best-law-schools-rankings.

6. See Mindie Lazarus-Black \& Julie Globokar, Foreign Attorneys in U.S. LL.M. Programs: Who's In, Who's Out, and Who They Are, 22 InD. J. Global Legal STUd. 3 (2015). The authors point out that the two schools where they conducted their research are considered "regular" and are ranked in the top seventy-five by U.S. News and World Report. Id. at 11-12. The top tier is commonly considered to be the schools numbered in the top fifty, with the next fifty schools considered second-tier. In some cases, where two or more schools are ranked at the same number (e.g., there are three numbered twenty), the following number(s) are empty (in the 2015 rankings, there are three schools numbered twenty, but no schools numbered twenty-one or twenty-two). This means there are always approximately fifty schools in the top tier. See generally TOP-LAWSCHOOLS.COM, http://www.top-law-schools.com/rankings.html (last visited Oct. 9, 2014).

7. See Lazarus-Black \& Globokar, supra note 6, at 15-16. 
the discursive genre of the admissions essay orients itself to the powerladen structures that constitute the particular field within which the essay is playing, or to which it is addressed. ${ }^{8}$ They also use the Bourdieusian concepts of "cultural and linguistic capital" in relation to global citizenship and English language acquisition. ${ }^{9}$ The variety of tactics that applicants pursue in their essays as they navigate the contradictory goals required by the admissions process is fascinating to watch. The authors' focus is on the nature of the cultural and linguistic capital that foreign-lawyer applicants perceive they must demonstrate to gain admission to each of the LL.M. programs under consideration. At the same time, the authors are interested in what the essays might reveal about the statuses, life histories, and aspirations of foreign applicants.

I would like to pull the focus out a notch to place the matter at hand within a slightly expanded Bourdieusian theoretical framework. To that end, I will focus on Bourdieu's treatment of the legal field, primarily in his 1987 law journal article, The Force of Law: Toward a Sociology of the Juridical Field. ${ }^{10}$ As Bourdieu theorizes in relation to any semiautonomous field within society (where a structured, socially patterned, practice takes place), there is a division of labor. ${ }^{11}$ In the case of the legal field, that division of labor includes judges and courtrooms, lawyers, law firms, government legal practice, and law schools. Legal education has equal standing with the other subfields, because law school is where future legal actors (lawyers, judges, legislators, and legal scholars) develop the capacity and authority to interpret the texts that determine the law. ${ }^{12}$ The stability of each field and subfield within the field (according to the division of labor) is operationalized and defined by its habitus, which involves deep structures of behavior and

8. Id. at 31-32 (citing Pierre Bourdieu, Outline of a Theory of Practice 21-22 (Richard Nice trans., Cambridge University Press 1977); WILlLAM F. HaNKS, LANGUAGE AND CoMmunicative PRACTICE (1996)).

9. Id. at 34 .

10. Pierre Bourdieu \& Richard Terdiman, The Force of Law: Toward a Sociology of the Juridical Field, 38 HASTINGS L.J. 805-53 (1987). In that article, Bourdieu uses concepts developed earlier that continue to have analytical purchase. For a selection of his work that predated The Force of Law see, for example, BOURDIEU, supra note 8; PIERRE BOURDIEU, Distinction: A SOCIAL CRITIQUe OF THE JUDGMENT OF TASTE (Richard Nice trans., Harvard University Press 1984); Pierre Bourdieu, The Forms of Capital, in HANDBOOK OF THEORY AND RESEARCH FOR THE SOCIOLOGY OF EDUCATION 241-58 (John G. Richardson ed., 1986); PIERRE BOURDIEU, IN OTHER WORDS: EsSAYS TOWARDS A REFLEXIVE Sociology (Matthew Adamson trans., Stanford University Press 1990).

11. Bourdieu \& Terdiman, supra note 10 , at 817 .

12. Pierre Bourdieu, In OTher Words: Essays Towards a Reflexive Sociology 817 (Matthew Adamson trans., Stanford University Press 1990). 
practice. ${ }^{13}$ Habitus incorporates the doxa (matters that are taken for granted) and governs the manner of interactions within the field, including the ways that players in the field differentiate between insiders and outsiders or elites and masses (as the USN rankings differentiate top-tier schools from the others). ${ }^{14}$ Society's rewards are distributed according to the operation of the field, which is governed by the accumulation, reproduction, and distribution of "symbolic capital." Symbolic capital includes "authority, knowledge, prestige, reputation, academic degrees," and is ultimately "convertible into the more traditional form of economic capital."15

The stakes are high because legal education is not just a vocational training program. The skills acquired in law school, when put into practice, reinforce the symbolic effectiveness of the law-law that determines practical effects while always appearing to be above the fray. ${ }^{16}$ This claim to universality and the practice that "proves it" are crucial to the entire project. Law school is where the habitus of legal practice is first encountered and inculcated. It is also where symbolic capital is accumulated and distributed in the first instance. In law school, future legal actors learn how to operate in the legal field. It is a "social space organized around the conversion of direct conflict between directly concerned parties into juridically-regulated debate between professionals acting by proxy." 17 Law students learn to compete in the legal field while also learning to successfully promote the aura of being objective and ethical. They learn how to exercise the power that constitutes and perpetuates the field of legal specialists with their specialized language. ${ }^{18}$ Therefore, that there have always been struggles over who gets to walk through the law school's doors-the gateway to the powerful legal field-is not surprising.

With this framework in mind, it is instructive to consider how the growing importance of USN rankings in light of increased competition for the reduced number of Juris Doctor (JD) applicants has affected the accumulation and circulation of symbolic capital in the legal education field. What happens when the habitus of a field is disrupted, whether by a powerful USN ranking system, by a "crisis" of the legal profession and

13. Bourdieu \& Terdiman, supra note 10 , at 807,811 .

14. Id. at 810 .

15. Richard Terdiman, Translator's Introduction to Pierre Bourdieu, The Force of Law: Toward a Sociology of the Juridical Field, 38 HASTINGS L.J. 805, 812 (1987).

16. BOURDIEU, supra note 12 , at 830 .

17. Id. at 831 .

18. Id. at 829 . 
hence of legal education, ${ }^{19}$ or by a rapid increase of LL.M. programs and the concomitant influx of foreign-lawyer students? In my view, those disruptions, rather than shaking up the lines of division, perpetuate them and perhaps entrench them even further.

The drive to quantify, and the public's perceived need for an easy way to choose and boast, feeds the hegemonic status of USN law school rankings. Just a few minutes on Facebook or BuzzFeed will confirm the enchantment and irresistibility of numbered lists. ${ }^{20}$ Even the notion of "trending" reinforces the desire to read or follow the top-numbered events (or celebrities) of the moment. While not the cause of competition among law schools, USN ranking is certainly instrumental in shaping the competition for applicants. ${ }^{21}$ USN's law school ranking has reinforced the operation of distinction by indicating which law schools are playing in "the big league" (i.e., the top fifty), and which are relegated to the second, third, and fourth tiers. All of this is based on a definition of quality whose effect has been to reinforce assumptions about what is needed to make "good" (meaning successful) lawyers in the U.S.- success most often considered a high-paying big law firm job in a major metropolis. ${ }^{22}$ The USN ranking system, introduced in 1990 and tweaked over the last decade (in 2004 and again in 2010 when it expanded its numbered ranking to include newly ABA-accredited law schools ${ }^{23}$ ), is a quintessential example of what Bourdieu calls "misrecognition." 24 Misrecognition is "induced misunderstanding" or the "process by which power relations come to be perceived ... in a form which renders them legitimate," and it reinforces the hierarchy of law

19. See Garth, supra note 3 , for a critique of scholarship on the current "crisis" and a trenchant analysis of its similarity to the crisis of legal education and the legal profession of the 1930 s.

20. See Paul L. Caron \& Rafael Gely, What Law Schools Can Learn from Billy Beane and the Oakland Athletics, 82 TEX. L. REV. 1483, 1553 (2004) (reviewing MICHAEL LEWIS, MONEYBALL: THE ART OF WINNING AN UNFAIR GAME (2003)).

21. Garth, supra note 3 , at 526 .

22. TAMANAHA, supra note 4 , at 112 .

23. Michael Sauder \& Wendy Espeland, LaW School admission Council Grants REPORT 07-02, FEAR OF FALLING: THE EFFECTS OF U.S. NEWS \& WORLD REPORT RANKINGS ON U.S. LAW SCHOOLS 2 (2007).

24. Law school deans and the Law School Admission Council (LSAC), which administers the Law School Admission Test (LSAT) have consistently objected to the ranking system. Law Schools and Reputation, LAW SCHOOL ADMISSION CoUNCIL, http://www.lsac.org/jd/choosing-a-law-school/s-reputation (last visited Oct. 7, 2014). A letter signed by almost all the deans of ABA-accredited law schools objecting to the method of ranking and the failure "to measure many factors that students claim are most important" was sent each year to all students who registered to take the LSAT. Sauder \& Lancaster, supra note 3 , at 111 . The deans are concerned with factors that remain unmeasured, including "racial and gender diversity within the faculty and student body." Id. 
schools by structural means. 25 Regardless of which factors are emphasized to delineate "quality," competition is defined by the field in which it plays. In this case, the legal education field and all who play in it understand the terms of the competition and the most highly valued factors. Like the law itself, USN ranking carries the power of raming, and, by publicizing the ranking, it distributes differing amounts of symbolic capital to the players. ${ }^{26}$

Because of the differential symbolic capital that comes from USN rankings, law schools redistribute resources and step up gaming strategies to ensure the highest possible ranking. A crucial gaming strategy, mentioned at the opening of this Comment, is to increase expenditures on merit scholarships with an eye toward encouraging students with higher LSAT scores to attend, what was earlier termed as "buying" higher LSAT scores. ${ }^{27}$ As Sauder and Espeland (2007) report, "many admissions administrators explained that [the] increase in money spent on merit scholarships has corresponded to a sharp decrease in need-based scholarships." ${ }^{28}$ This gaming strategy has led to serious concerns about its impact on student diversity, particularly since the USN factors do not include a diversity component. ${ }^{29}$ Here is where the rise in LL.M. programs for foreign lawyers fits into the picture-since LL.M. programs are neither separately ranked nor included in the general law school rankings, tuition income from foreign-lawyer students can be used to increase merit scholarship offers.

Returning to the article under consideration, this well-known ranking gaming strategy is reflected in comments from law faculty that Lazarus-Black and Globokar heard at conferences where they presented earlier versions of their article. ${ }^{30}$ Law professors in the audience would insist that LL.M. programs for foreign lawyers are nothing more than "cash cows." ${ }^{1}$ The authors take exception to this characterization, and

25. Bourdieu \& Terdiman, supra note 10 , at 813.

26. BOURDIEU, supra note 12 , at 838.

27. SAUDER \& ESPELAND, supra note 23, at 10.

28. Id. at 11 .

29. Id. at 12 .

30. Lazarus-Black \& Globokar, supra note 6, at 26 n.67.

31. Id. Although faculty voices themselves are not heard very much in the article, presumably due to the decision to focus on administrators and foreign LL.M. students, we do catch a glimpse of some classroom issues through administrators who report feeling pressured by faculty to limit numbers of foreign students to avoid slowing down classes and requiring longer office hours. Later in the article, gleaning information from the administrator interviewees, the authors mention faculty interest in comparative and international law, as well as networking and teaching abroad opportunities that might be created through their LL.M. students. Id. at 26 . The authors might bolster their argument that foreign students do more than provide needed income with faculty voices about the 
their research shows there is more to LL.M. programs than financial gain. Lazarus-Black and Globokar point to a more diverse LL.M. student body-in nationality, ethnicity, gender, and economic background-among the second-tier schools they studied than the public is led to expect. ${ }^{32}$ They are not simply members of elite families who come for credentials that will add to their chances of election and appointment to government leadership positions. The foreign-lawyer LL.M. students whom the authors interviewed (and whose admissions essays they analyzed) include, for example, middle class women who plan to use the degree and the English proficiency that comes with it to advance in their professional lives. ${ }^{33}$ Also, through their research, the authors "are able to debunk some of the stereotypes that 'all' foreign law students hail from the highest economic echelons of their countries of origin and that they are 'only' interested in business and making money." 34 In fact, the authors' themes of "upward mobility" and trying to "surmount gender [and] class barriers" 35 are critical to understanding what these "regular" schools offer foreign lawyers who, although they cannot attend the top schools, are willing to do what it takes to get an LL.M. degree.

This brings us back to Bourdieu's notion of symbolic capital. As the authors' research reveals, the growth and expansion of LL.M. programs into law schools below the top tier provide opportunities for a variety of foreign lawyers who gain symbolic capital that can be accumulated and then deployed at home. ${ }^{36}$ However, does symbolic capital also flow in the other direction? Do law schools accumulate symbolic capital through expansion of these LL.M. programs? ${ }^{37}$ The authors identify a certain degree of additional diversity that foreign lawyers add to the mix of the law student body that may or may not increase the school's symbolic capital. ${ }^{38}$ The authors also cite research by Carole Silver to the effect that such a program might enable a law school to boast about its international and global character or claim to contribute to the

relationship among their scholarly interests, teaching comparative and international law to U.S. law students, and the participation of foreign lawyers in their classes.

32. Lazarus-Black \& Globokar, supra note 6, at 11.

33. Id. at $47-49$.

34. Id. at 31 .

35. Id. at 17,63 .

36. Id. at $45-46$.

37. For the few schools that are sitting on the cusp of the top tier, a single place upward can mean an increase by as many as 180 JD applications per year. See SAUDER \& ESPELAND, supra note 23, at 30.

38. Lazarus-Black \& Globokar, supra note 6, at 56. 
"alleviation of underdevelopment." 39 Given these relatively minor potential benefits to a law school's reputation, the authors' primary interest is in negating, or at least softening, Brian Tamanaha's recent characterization of today's law schools as more homogeneous, both economically and racially, than in the past. ${ }^{40}$ Lazarus-Black and Globokar's study "revealed a [LL.M.] student body that was neither predominantly white nor male nor uniformly privileged." 41 If their research holds, classroom seats that used to be filled by non-white or lower and middle class JD students will increasingly be filled by a diverse group of LL.M. lawyer-students. As the authors admit, the addition of a diverse group of LL.M. lawyer-students does not reveal the entire story. They step back from too celebratory a stance to explain that LL.M.-created diversity may not solve the problem identified by Tamanaha of decreasing diversity and increasing elitism of law schools in general. ${ }^{42}$

Here is where another strategy being used to game the USN ranking system comes into play and reveals just how insidious the pursuit of the symbolic capital of ranking can be in legal education. Some law schools are reclassifying as "probationary" or "part-time" some first year students with lower LSAT scores, particularly if they are not white or are from poor backgrounds. ${ }^{43}$ This reclassification keeps the lower LSAT scores out of the pool reported to USN, and thus prevents the school's ranking from suffering. Before the current crisis began playing out fully, the total number of law schools was growing substantially, thus providing avenues to upward mobility for U.S. college students from a broad range of previously excluded backgrounds. Law schools became more inclusive, and even if many of those students were attending schools below the top tier, those students benefitted from the symbolic capital that the law degree conferred. ${ }^{44}$ Assuming that inclusiveness is an important value, as evidenced by law school deans' objections to USN's failure to include diversity in its "factors of excellence," 45 law school should be accessible and its access should be as equitable as possible. Otherwise, given the "powerful position of law in the governance of the state and the economy" and the "greater role for law in the governance of the global economy," unequal distribution of

39. Id. at 28 (citing Carole Silver, Internalizing U.S. Legal Education: A Report on the Education of Transnational Lawyers, 14 CARDOZO J. INT'L \& COMP. L. 146, 154 (2006)).

40. TAMANAHA, supra note 4, at 86-87, 130.

41. Lazarus-Black \& Globokar, supra note 6 , at 57.

42. Id. at 56-57.

43. SAUDÉR \& ESPELAND, supra note 23 , at 13.

44. Garih, supra note 3 , at 526.

45. For USN's criteria and methodology, see Flanigan \& Morse, supra note 5. 
symbolic and economic capital will be reinforced beginning with the law school admission process. ${ }^{46}$

The two gaming strategies discussed above, taken together, reveal a disturbing picture-the ghettoization of students (U.S. and foreign) whose presence in law school may be a liability for the school's ranking. Ultimately, that ghettoization leads to a developing hierarchy within law student populations, reinscribing an older version of law school as an elite enterprise - when those in the golden circle count and those outside do not. If that hierarchization is one of the necessary costs of diversifying law student bodies in the United States as schools become ever more desperate to move up in the rankings, scholars researching those phenomena must consider how symbolic capital is accumulated, reproduced, and distributed within the field of legal education. In that regard, I would like to echo the authors' call for research that spans a cross section of law schools. ${ }^{47}$ Lazarus-Black and Globokar have given us a taste of how painting all foreign LL.M. programs with the brush of elitism and assuming they are simply "cash cows" can lead to a misinterpretation of the possible roles foreign-lawyer students can play at differently tiered law schools. Understanding how the entrenched ratings system affects the future of legal education requires careful consideration of the unintended consequences of gaming that system.

46. Garth, supra note 3 , at $\mathbf{5 1 9 .}$

47. Lazarus-Black \& Globokar, supra note 6 , at 63. 